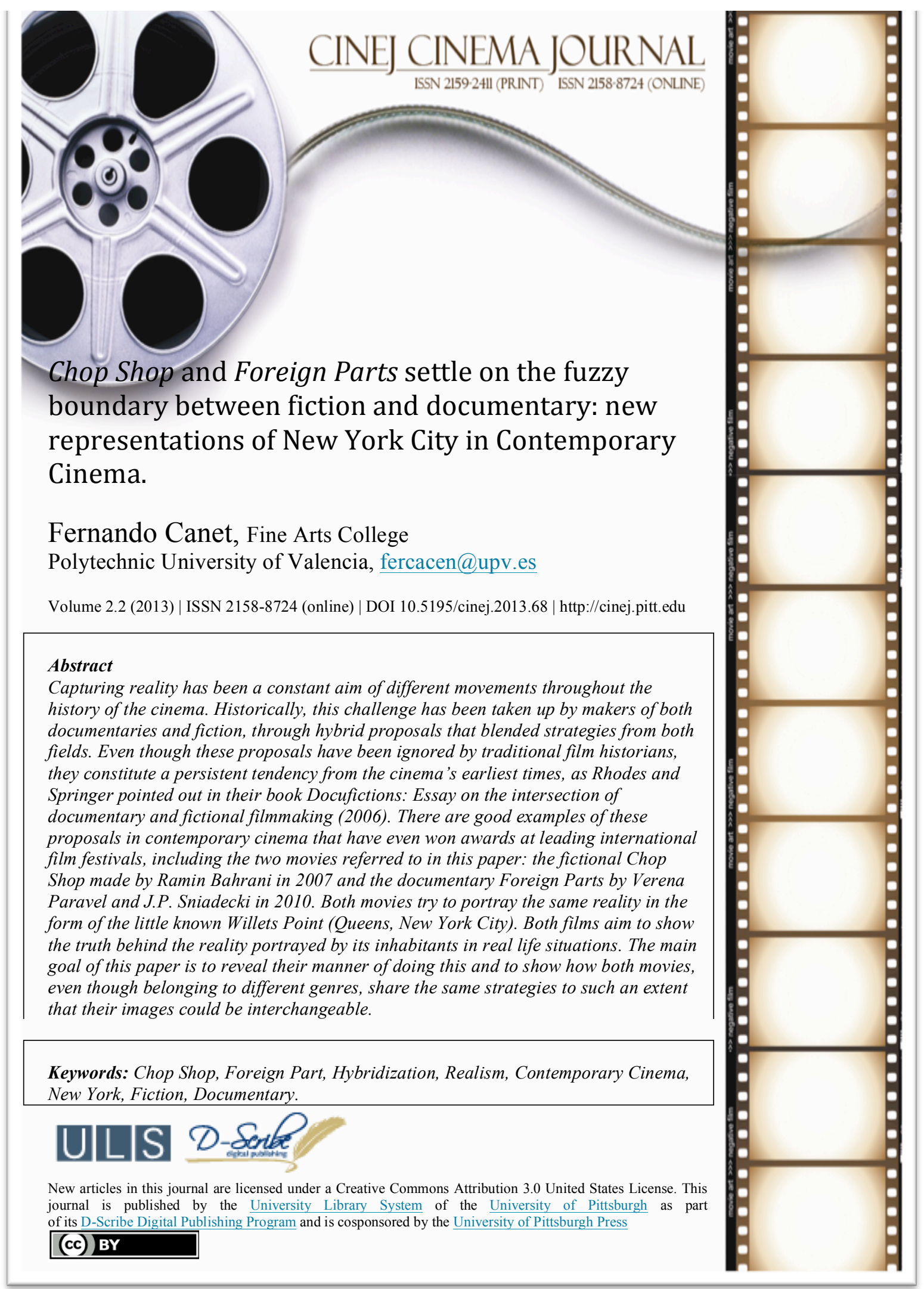




\section{Chop Shop and Foreign Parts settle on the fuzzy boundary between fiction and documentary: new representations of New York City in Contemporary Cinema. ${ }^{1}$}

\section{Introduction}

Godard once said, "All great fiction films tend toward the documentary, just as all great documentaries tend toward fiction". The boundary between documentary and fiction is precisely the main interest of this paper. Hybrid proposals have been questioning the dichotomy, as old as the cinema itself, between reality and fiction. In such cases, the boundaries between documentary and fiction may become blurred for those directors who are seduced into experimenting with them. Hybrid approaches which follow alternative forms of the mainstream discourse are also to be seen in contemporary cinema.

Joaquín Jordá (Zunzunegui, 2007: 200), in an interview said,

"The boundaries between documentary and fiction do exist and are increasingly interchangeable. I think the current trend in the cinema demonstrates that I am right. The people who make fiction in the most interesting way for me are those entering what we formerly considered documentary techniques. At the same time, the documentary is entering at least in my case I try to make this happen - into elements previously considered to be exclusive to fiction. In this way we heal the division, which was always more theoretical than practical, between Méliès and Lumière..."

This division is between the reality takes of the Lumière brothers on the streets of Paris on one hand and the staging of imaginary events by Méliès in his Paris studio on the other.

As stated in the introduction to the book edited by Rhodes and Springer (2006: 3), "Traditional histories of film tended to ignore the frequent intermingling of documentary and fictional devices in narrative films, which constitutes a persistent tendency in the cinema from its very beginning". Although in 1939 Rudolf Arnheim already introduced the concept of "half-documentary" to refer to the films made by Robert J. Flaherty up to that time, it was not until the last decades of the last century that critics and theorists began to recognize and bring forth productions that were defined mainly by their creative use of hybrid codes. Indeed, several theorists have recently proposed new terms to define these hybrids, for example Docufictions proposed by Rhodes and Parris in the introduction to their

\footnotetext{
${ }^{1}$ The research for this article was enabled with the support of the Research Project 'Study and analysis for development of Research Network on Film Studies through Web 2.0 platforms', financed by the National R+D+i Plan of the Spanish Ministry of Economy and Competitivity (code HAR2010-18648).
} 
book (2006: 5). Other authors have also proposed their own terms, such Jacques Rancière (2006: 38), who uses the term 'documentary fiction', Kent Jones (2005), who uses 'fiction-documentary hybrids' and Rodríguez-Mangual (2008: 299), who opts for 'fictual faction'.

On the other hand, there are attempts to represent either the reconstruction of historical events or immediate reality using codes from both fiction and the documentary, and others that narrate fictional content using documentary strategies to give it false authenticity. Among all these alternatives, the core of this work focuses especially on those proposals whose content is the reality around the author and his times, such as that portrayed by the Lumière brothers in their earliest films or by Dziga Vertov a few decades later in the first productions of the Soviet government, the Kino Nedelia (Film Week, between 1918 and 1919).

The specific reality described in this research is relatively unknown, although paradoxically it belongs to the city most often portrayed in the history of the cinema, the Willets Point neighborhood in New York City. It could also be described as one of the most neglected areas of Queens. Willets Point is popularly known as the Iron Triangle for its chop shops, or workshops that break up stolen cars to sell for spare parts. Mayor Bloomberg described it as another euphemism for urban blight. The neighborhood itself looks more like an area in any of huge city in the developing world, rather than one of the most glamorous cities in the world. Of course it has nothing to do with Woody Allen's cinema or conventional commercial films. In this other New York reality, there are neither skyscrapers, Fifth Avenue stores, smart restaurants, Central Parks or Broadway theaters. Viewers will not find vestiges of the grand Manhattan or other famous landmarks of the Big Apple. This would be an unattainable reality for the people that have resigned themselves to living in another apple, in this case the slums of Willets Point.

In the last years, two filmmakers have come to Willets Point with the intention of portraying that other reality of the multifaceted city. The first film is Chop Shop, released in 2007, and the most recent is Foreign Parts, which was first shown in 2010. The former was directed by American-born Ramin Bahrani, of Iranian origins. This filmmaker has tried, despite the considerable distance involved, not to lose his cultural roots by keeping in contact with the well known Iranian filmmaker Abbas Kiarostami, who we could define as his film-making godfather. Foreign Parts is directed by two filmmakers who are also researchers at Harvard University: one is also an anthropologist, Verena Paravel, of French origin and a member of the research group at the Center for Film Studies at Harvard (Harvard's Film Study Center). The other is JP Sniadecki, born in the U.S. but currently in Beijing doing field work for his doctoral thesis in the Department of Social Anthropology at Harvard University. 
To sum up, this paper studies a fictional film Chop Shop, which uses strategies, resources and codes of the documentary to present the authentic face of the reality that it seeks to portray. Also studied is the film Foreign Parts, which, in spite of being a documentary is seduced by fictional strategies into developing the characters. I therefore deal with two hybrid proposals, one from the field of the documentary and the other from fiction, which were conceived in the no-man's land between the two categories and contain facets of both. I have tried to steer clear of the orthodox approach in order to be able to consider alternatives to the mainstream discourse.

\section{Location as the inspiration for a story: the Willets Point neighbourhood.}

As will be seen, both films offer an ethnographic ride to a particular diegetic universe, full of dismantled cars, unpaved dirt streets in which the puddles only disappear during the hot days of summer, are flooded when it rains, full of trash, illegal immigrants and petty criminals. Chop Shop in the local slang means an undercover workshop where stolen cars are broken up for spare parts to be sold on the black market, thus making the whole area an authentic junkyard. It was, in fact, precisely this gray world of poverty that inspired the directors to make the film. Thus, as in all the movies made by American filmmaker Frederick Wiseman, the set itself was the starting point of the stories in both films.

Verena Paravel came across Willets Point quite by chance. While she was shooting 7 Queens on the Line 7 subway, which connects Times Square (Manhattan) with Flushing Avenue (Queens), one of the city's most interesting routes in ethnic terms, she found herself in the exciting reality of Willets Point. Someone advised her to run away from there, it could be dangerous for a woman and more so for a woman with a camera in her hand. As Paravel said, the first time she came into Willets Point a guy with a forklift took a car and threatened to drop it on her head if she kept shooting. This experience impressed her so much that her film begins with the noise of a forklift on a black screen, then the scene shows a forklift chopping a car into pieces. However, the initial unpleasant experience did not frighten her away but did quite the opposite, fascinated by the location, she immediately decided to make her next film there. So she came back to Willets Point for a longer stay in order to get to know it better and with hopes that those initial problems would not recur.

Bahrani had a somewhat similar experience in those muddy streets full of stripped down cars. His cinematographer, Michael Simmonds, came to Willets Point looking for a spare part for his car, immediately fell in love with the place and told Bahrani about it. After visiting the neighborhood in the winter of 2004, Bahrani, motivated by that inner drive to understand a subject, whether it is far away or just around the corner, decided to make what would be his second feature, Chop Shop, a project that came to fruition three years later. Unlike Foreign Parts, this film lifts 
the curtain by placing the story in context. The director chooses a location outside the neighborhood to focus on the distant skyscrapers of Manhattan, as if letting the audience know from the beginning, this is, but does not seem like, a story set in New York City. A similar statement is also made in Foreign Parts, although in this case the idea is expressed in a more general key at the end of the movie. In one of the closing shots, we see the ubiquitous American flag in the foreground while daily life continues in one of the main streets of Willets Point in the background. This image appears to say this is also part of the American dream.

Unlike Chop Shop, the contextualization in Foreign Parts is gradually unfolded throughout the movie, which is shot entirely within the confines of the neighborhood. Even though, as mentioned above, a forklift gets the viewer's full attention in the opening shot, it also reveals the New York Mets' new stadium in the background. However, the presentation of the Shea Baseball Stadium, synonymous with New York City, is quite subtle, and largely unnoticed by most of the public. This theme will return time after time during the film. However, the Mets Stadium is not the only evidence in both films to suggest the invisible presence of New York City; another two icons of the city also acquire prominence; on the one hand, the presence of the subway is required in many of the establish shots, and on the other hand, although to a much lesser extent, the presence in scenes of the very popular New York police.

Both films make use of the first world symbol of the nearby Mets Stadium as a contrast to the third world Willets Point. For Bahrani it was paradoxical to observe how quickly you could migrate from a hopeless place to another where you could read on a giant billboard "Make Dreams Happen". Bahrani confesses he was curious to know "What dreams can happen in this place?" or in other words, how can the American dream be so close yet so far away for those who live in Willets Point? In fact, in this city one is constantly aware of the geographical proximity of such socially and culturally distant worlds.

However, this physical proximity to the dream may soon come to an end as Willets Point has become the target of urban speculation. In 2008 Mayor Bloomberg approved a redevelopment plan that will convert it into a residential and commercial area. Over 2000 men and women working in about 250 shops in this neighborhood will thus have to find another way of earning a living. The plan is strongly criticized in Foreign Parts, mainly by one of its oldest residents, 76-year old Joe Ardizzone, who faces eviction. In his words: "If the city invested in infrastructure, rather than leave the poor and surrender the area to friends of the mayor, would be drawn to small businesses that employ local labor" and describes the mayor as a traitor to the American dream.

Foreign Parts thus condemns the transformation that enriches a few while harming the majority. On the other hand, and also linked to the idea of change it tries to capture a reality that will soon disappear, perhaps the same motive that encouraged 
Flaherty to film the customs of the Inuit in his film Nanook of the North (1922). As he said, "I wanted to document these traditions before they disappeared." Foreign Parts in this respect is similar to Pedro Costa's In Vanda's room (2000) and Colossal Youth (2006), or two films set in Barcelona, José Luis Guerin's Work in progress (2001) and Joaquín Jordá's De nens (2003). In the words of the latter Barcelona is "A city in which, from time to time, a few people find an opportunity to redevelop, to increase the power of capital over the city, to make it more friendly and reduce conflict." (Zunzunegui, 2007: 204)

Another aspect that both Foreign Parts and Chop Shop have in common with these movies is their sympathy for its under-privileged inhabitants. They all give voice to the lowest social class who live isolated and disillusioned in the worst districts of big cities. It gives voice to those, says Trinh T. Minh-Ha (2007-2008: 232),

"The silent common people, those who have never expressed themselves unless they are given the opportunity to verbalize their thoughts by those that come to redeem them, are constantly called to represent the real world. From the social aspect, they are the fundamental reference, so you can just approach them with the camera, showing their poverty (industrialized) or contextualize and package their unknown lifestyle for the ever-present consumer and generous general public on "this side" to enter the hallowed realm of the morally or socially correct."

One of the earliest references to this trend is in the movie Housing Problems directed by Elton and Anstey in 1935. It was shot on location and its most interesting contribution is to give the leading characters the unusual opportunity of telling their personal dramas in the first person. Ultimately, these kinds of films offer the opportunity of self-expression to those people excluded by the commercial cinema and confined to social ostracism by the society. In the words of Erving Goffman, such films choose to represent reality through the "presentation of the person in Everyday Life". Humphrey Jennings was one of the pioneers of this technique within the group known as the Free Cinema. Lindsay Anderson (1954), one of its leading members and a disciple of Jennings, defined Jennings' style as:

"A style based on a peculiar intimacy in the way of observing, a fascination with ordinary people or things that are meaningful precisely because of their triviality, and an interest in the outline that emerges when those common but significant things and folks are combined in the right way."

In both Foreign Parts and Chop Shop the audience can see how the characters break up, sand, polish and paint cars, change tires or lure customers to their shops. If in Foreign Parts the performers are anonymous workers, in Chop Shop the leading character is Alex, a 12-year old boy, whose actions are followed by the camera from the beginning to the end of the story. In addition to showing people at 
work in Willets Point, both films also show people in their time off, having fun playing dice or enjoying barbecues, while the ever-present Latin music can be heard blaring out in the background.

\section{Hybrid forms and the representation of reality.}

So far I have outlined the reality that both films have tried to portray, and now I will focus on how far this reality has been captured by each, looking for points of agreement in these hybrid forms that are neither pure documentary nor pure fiction. This encounter aims mainly at representing reality in the most authentic way possible and will inevitably lead us to the Realism movement in the history of filmmaking. Bazin (2004: 299) was one of the first to theorize about this style of filmmaking with ideas like, "We therefore call realistic any system of expression, any proceedings of telling, which let us show a greater degree of reality on the screen." Bazin was here mainly referring to Italian Neorealism, which is approached from fiction. However, the history of cinema also offers us an even earlier approximation to reality, because the medium itself was born with the aim of capturing reality, and those who first did this, specifically in the streets of Paris, were the Lumière brothers. In the twenties, reality is also the benchmark for two filmmakers who approach it from different perspectives; I refer on the one hand, to Dziga Vertov and his newsreel series Kino-Pravda (Film Truth), and on the other to Robert J. Flaherty. Other proponents of this approach were the British documentary makers with John Grierson at the forefront, who began to operate in the thirties and forties, also the British Free Cinema of the fifties with its kitchensink realism. Others were the French Cinéma Vérité with Jean Rouch at the forefront and the American Cinema Direct as practiced, among others, by Richard Leacock.

Even though Foreign Parts and Chop Shop are on different sides of the dividing line, they both try to approach reality in the most authentic way possible. With this approach, the fiction films must make a bigger effort to achieve higher levels of authenticity because their form of expression, based on the staging, is not helpful for that purpose, so that fiction films have historically had to make use of strategies and codes from the documentary to achieve a greater sense of realism. Bill Nichols (1991: 167) put it as follows, "Neorealism, as a fiction film movement, accepted the documentary challenge to organize its aesthetics around the representation of everyday life, not simply in terms of topics and character types but in the very organization of the image, scene, and story."

The challenge that Nichols speaks about was perhaps first put into practice in New York by Edison and his staff. As mentioned above, while the dialectic between documentary and fiction was being played out in Paris, at the same time in New York certain hybrid forms were coming to light which used the technique of staged reality. That is, reality was first observed and then recreated by staging 
using the documentary techniques of the time, so that to the viewer the images that appeared on the screen could have been recorded directly from real unstaged sequences. One example is the advertising film recorded by Edison and Dickson called Blacksmith Scene (1893), which features three blacksmiths working and enjoying a beer. Even though the scene looks real, it was played not by real smiths but by Edison's employees acting out the scene in his study.

Another early example of the hybrid approach to reality is Flaherty's Nanook of the North (1922). Flaherty had to return to the Barren Lands when he recognized that his first editing failed because the overall result was episodic.

"I had just completed editing the film in Toronto when the negative caught fire. The editing print, however, was not burned, and this was shown to some private groups several times - just long enough, in fact, to enable me to realize that is was no good. I knew then that the reason I had missed out was that the whole thing was episodic. But I did see that if I were to take a single character and make him typify the Eskimos, the results would be well worth while." (quoted by Sherwood, 1979: 17-18).

Flaherty went back in 1920 to shoot his film again, making Nanook and his family the stars of the film. He spent fifteen months with them earning their complicity, finally achieving realistic sequences of their everyday life. As Robert Sherwood notes (1979: 15-16), 'the backbone of every motion picture is the continuity,' and to frame this continuity, 'Flaherty selected one character, Nanook himself, to serve as the protagonist of his drama.' However, his characters were not fictitious like those of his contemporary D. W. Griffith, but real people who inhabited the real spaces that he wanted to portray. Thus, Flaherty appropriated narrative strategies, particularly the construction of character, in order to represent reality. Through tracking the lives of these people, Flaherty vested the documentary with temporal continuity as well as dramatic structure.

As Jean Rouch claimed in his first short film, Initiation à la danse des posseder (1949), an essential condition of portraying reality is to be a part of it. Foreign Parts was filmed over two years, covering all four seasons, or the time that any ethnic process needs to reach the stage of going native, when the camera is no longer noticed by the people. But not only is it desirable that the mechanism itself becomes invisible to the inhabitants of the environment, it is also advisable for the crew to become integrated in the daily life of the world it is supposed to be portraying. In the case of Foreign Parts the crew integrated with the world they were filming to such an extent that all the scenes convey a convincing naturalness. For example, the joy that Luis and Sara, two of the characters in Foreign Parts, feel in a scene toward the end of the film, on being reunited after Luis's long absence is shared by the directors, who in an improvised way are involved in the action as well. 
Just as it is crucial for a documentary to coexist with reality, the same can be said for fiction films. If a documentary needs a certain time for the people to get used to the presence of the camera, it is also true for fiction, not only during the shooting but even during research and writing the script. Bahrani himself admits in his film's pressbook that he spent a year trying to become part of the world of the Latino children who spent their time in the workshops or roaming the streets: "I became increasingly interested in the lives of these young boys who worked and lived amidst grown men, in this very tough location. I wanted to know who they were, what kind of dreams they had, and how they managed the challenges and decisions that most of us as adults never have to face." Thus, the main character in Chop Shop is Ale (Alejandro Polanco) a child growing up on the street, who has to struggle with the hostile environment. This also occurs, for instance, in Vittorio de Sica's Shoeshine (1946), Roberto Rossellini's Germany Year Zero (1948) and Luis Buñuel' Los Olvidados (1950). As Bahrani himself recognized, "If [Luis Bunuel's] Los Olvidados were to be made today in America, it would be made here", referring to Willets Point.

Even though Alejandro is Latino, speaks Spanish, and is not a professional actor, he doesn't really belong to the group described above. He was born and grew up in Lower East Side in Manhattan. However, Bahrani knew how to solve this problem by sending Alejandro to imbibe the local conditions. He thus spent six months in Rob Sowulski's shop -the real owner, who also plays himself in the film- before shooting started, learning firsthand the skills he would need rather than interpreting them in front of the camera. Alejandro says in the report of the movie "Every day I would get like $\$ 30$, I learned how to sand down cars, paint cars, and how to fix dents. I even learned how to drive! It was really hard but a lot of fun." He thus managed to be part of the neighborhood, making friends and getting respect from adults to the point that, as the director said, "People in the Iron Triangle thought we were making a documentary about Ale, a boy who worked there, because they'd really seen him working there for so long."

Another strategy that brings the film closer to the truth is to allow the actors to improvise when shooting a scene. When taking spontaneous footage both of the actors and the location, Bahrani never says "action" or "cut", so that sometimes even the crew cannot distinguish between the script and the improvisation. Moreover, he often aims for spontaneity by changing the situation without telling the actors. As Vertov believed, the only way to make the sequence more real is precisely through spontaneity.

According to José Luis Guerin (Monterde 2007: 121) "Better than thinking in terms of reality and fiction, it seems more enlightening to think in terms of control and randomness." This is particularly true in situations where the staging gives way to capturing the actions of real people, when the only controlled aspect of the situation is the action of the main character. This happens in the scenes in which Ale and his friend Carlos sell candy on the subway or when Ale is waiting for his 
sister on the platform. In the first case a small crew with a hand-held camera is the only way to shoot the scene without altering the environment in which the action unfolds. In the second case, the effect is achieved by using lenses in a selective approach that keeps Ale in focus at all times, even though he often disappears into the crowd waiting for the train. Both scenes are especially reminiscent of the neorealistic scenes inside the bus and with the public at the train station. Bazin (2004: 313) referring to such scenes, said: "The subtlety and flexibility of the camera movements in these tight and crowded spaces, and the natural behavior of all persons in frame, are the main reasons that make these scenes the highlights of Italian cinema."

Bahrani and his cinematographer decided that they must follow documentary techniques if they wanted to evoke a high degree of naturalness and authenticity and that the actions in every scene must be kept as simple as possible. As he expressed it: "In almost all of our conversations about how to shoot it, we would say, 'What's the simplest way?' Almost every scene is one shot, with sometimes quite complicated mise-en-scene, even though it may appear simple". Bahrani thus follows Bazin's theory, in thinking that editing the film should be prohibited because it breaks the natural flow. In this context, the words of Trinh T. Minh-Ha (2007-2008: 228) become especially relevant:

"Real time is considered more 'credible' than film time, so that the long take... and to edit a minimum or not to edit ... is considered the most appropriate to avoid distortions in the structure of material... Thus, the close up shot is condemning by its partiality, while a wide shot angle is considered more objective because it covers more on the screen and, therefore, may reflect more accurately the event in context."

If improvisation is one of those blank firing guns that fiction can borrow from the documentary, intervention at the location would be its counterpart, a "harmless" device that the documentary borrows from fiction. This is done with the intention of emotionally identifying the spectator with the real people selected to unfold the plots of the film.

Three plots are unfolded in Foreign Parts: the first is the one featuring Joe Ardizzone, mentioned above, the second features Julia, a black woman known as "The Queen of the Junkyard", and the third focuses on the relationship between Luis and Sara, also mentioned above. Luis is from Puerto Rico while Sara, as she describes herself in the movie, is "the only white woman in the neighbourhood". It takes approximately twelve minutes to present the background to the story, in the observational style, before these characters are brought into the discourse. From then on the structure of the film alternates between observing these characters and presenting further facets of Willets Point. However, as the film progresses, it focuses more and more on Joe, Julia, Luis and Sara. We are thus invited to undergo a film experience in answer to Jean Breschand's question "How do you 
live?" (2004: 85). As I mentioned above, the movie gives an opportunity to those underprivileged people without voices, who are invisible to most of society, to express their frustrations with the situations in which they have to live.

Tracking the lives of these characters provide continuity and a sense of time as well as giving a dramatic structure to the document, e.g. the relationship between Sara and Luis. The couple is introduced and we are shown how they earn a living and where they live. The movie then jumps to cold-hearted winter and a turning point is introduced when Luis has to leave the neighborhood, which causes problems for Sara. However, Luis comes back home and we rejoice when they are reunited and things begin to improve. Finally, we find it is summer and everything comes back to normal. The plot follows the changing seasons, through abrupt cuts to rain, snow, rain again and finally the sun, which only appears in the last scene. This sunlight should invite us not to optimism but rather to pessimism, since the neighborhood is doomed to disappear in the planned redevelopment.

Foreign Parts is itself a hybrid between two approaches that portray the cruelty of the present, between two styles of what has been called cinema of immediacy. It could be classified as somewhere between a purely observational proposal, suggested by Leacock and Wiseman, in which the filmmakers are not involved and wait patiently for the magic of reality to offer what they are looking for, and the interventionist style favored by Jean Rouch, in which they deliberately manipulate the situation. Foreign Parts thus borrows from two of the four sources specified by Nichols (1991: 65) in Representing Reality. At the beginning the movie is purely observational but then gradually becomes interactive as the filmmakers start to intervene in the action.

For example, when Sara is talking to the camera, she is suddenly interrupted by the director, who tells her someone wants to speak to her on the phone. The caller tells her that Luiswho has been absent for a while, will soon come back to the neighborhood. She gets excited, so the intervention has achieved its goal and the viewer emotionally identifies with the character. This movement from the Off to the In of the shot forces the discourse to cross a double border: on the one hand, the boundaries between documentary and fiction, through the dramatization of the situation, and on the other, the border between the areas behind and in front of the camera, breaking the hymen of cinematic transparency and emphasizing the selfawareness of the discursive mechanism.

The disappearance of the division between those who are in front of the camera from those behind it makes the movie cross over from the traditional territory of epistephilia, defined as the need to achieve and to transmit knowledge, to the land of gnostiphilia. According to Nichols (1991: 194), this is "A term we might use for knowledge not depending on distance, objectivity, and reasoned analysis alone but also on empathy, identification, feeling, tone, and sensitivity". This is achieved through the relationship established between the filmmakers and their characters 
and also extends to the viewers. In this way documentaries can approach fiction and its identification mechanisms.

\section{In conclusion}

The dialectical tension between fiction and facts in Chop Shop blends with a style that translates into being seduced by a combination of the control achieved through scripted situations and improvised acting in real locations. Foreign Parts achieves this from both direct observation of reality and the participation of the filmmaker to make the audience emotionally identify with the real people who are depicted in the film. It can therefore be said that the development of the characters contributes to the narrative structure of the film. Chop Shop and Foreign Parts can therefore be seen as two examples of contemporary hybrids from different sides of the divide between documentary and fiction, which blend strategies from both genres in their search for the authentic reality of Willets Point, which will soon become the mere ashes of the past, as F. Scott Fitzgerald anticipated in The Great Gatsby, describing Willets Point as a valley of ashes.

Through the search for utopian authenticity their respective directors approach the description of a true film artist made by Seigfried Kracauer (1997: 255):

"As a man who sets out to tell a story but, in shooting it is so overwhelmed by his innate desire to cover all of physical reality - and also the feeling that he must cover it in order to tell the story, any story, in cinematic terms - that he ventures ever deeper into the jungle of material phenomena in which he risks becoming irretrievably lost if he does not by great efforts get back to the highway he has left."

I began by quoting Godard and shall also end with another quote from the French director, bearing in mind the attempt these two films make to portray reality: "Film is truth at 24 frames per second". 


\section{References:}

Anderson, L. (1954). Only Connect: Some Aspects of the Work of Humphrey Jennings. Sight and Sound, 25, no 4, 181-6.

Bazin, A. (2004). ¿Qué es el cine? [What is cinema?]. Madrid: Rialp.

Breschand, J. (2004). El Documental [The documentary]. Barcelona: Paidós. Los pequeños cuadernos de "Cahiers du Cinema".

Jones, Kent (2005). 'I Walk the Line,' Film Comment, 41, 1, Jan/Feb.

Kracauer, S. (1997). Theory of film: The redemption of physical reality. Princeton, NJ: Princeton University Press.

Minh-Ha, T.T. (2007-2008). El afán totalitario de significado. Archivos de la Filmoteca, 57-58, no II, pp. 223-246.

Monterde, E. (2007) José Luis Guerín. In Al otro lado de la ficción. Trece documentalistas españoles contemporáneos [On the other side of fiction. Thirteen contemporary Spanish filmmakers], ed. Cerdán, J. and Torreiro, C. Madrid: Cátedra.

Nichols, B. (1991). Representing Reality. Indiana University Press.

Rancière, J. (2006). The Politics of Aesthetics. Continuum International Publishing Group.

Rhodes, G.D., Parris, J. (2006). Docufictions. Essays on the intersection of Documentary and Fictional Filmmaking. North Carolina: McFarland Company, Inc.

Rodriguez-Mangual, Edna M. (2008). "Fictual Factions: On the Emergence of a Documentary Style in Recent Cuban Films." Screen, 49:3 Autumn, 298-315.

Sherwood, R. (1979). "Robert Flaherty's Nanook of the North." In The Documentary Tradition, ed. Lewis Jacobs. Toronto: George J. McLeod Limited, 15-19.

Zunzunegui, S. (2007). Joaquín Jordá Catalá. In Al otro lado de la ficción. Trece documentalistas españoles contemporáneos [On the other side of fiction. Thirteen contemporary Spanish filmmakers], ed. Cerdán, J. and Torreiro, C. Madrid: Cátedra. 